\title{
LEARNING LANGUAGE NATURALLY: CHALLENGES AND OPPORTUNITIES
}

\author{
Wishnoebroto \\ English Literature Department, Faculty of Humanities, BINUS University \\ Jln. Kemanggisan Ilir III No. 45, Kemanggisan-Palmerah, Jakarta Barat 11480
}

\begin{abstract}
Experts believed that the best way in learning language is through natural process, which means that learning should go through process of understanding concept. Grammar and all language features are mastered through practice in certain context. This article tries to find a model of information technology that may be suitable for learning English but without leaving the main functions of textbook as the center for knowledge and information through an approach called the Dynamic Immersion Approach. This approach tries to mimic the process of children in learning language. From the analysis it shows that despite many advantages from the new approach this program cannot produce natural language since it lacks the capability of producing informal language.
\end{abstract}

Keywords: language learning, Dynamic Immersion Approach

\begin{abstract}
ABSTRAK
Para ahli memercayai bahwa cara terbaik dalam mempelajari bahasa Inggris adalah melalui proses alami, maksudnya pembelajaran tersebut harus melewati proses konsep pemahaman. Tata bahasa dan semua fitur bahasa dikuasi melalui latihan pada konteks tertentu. Artikel ini mencoba untuk mencari model informasi teknologi yang mungkin cocok dalam belajar bahasa Inggris namun tanpa meningggalkan fungsi utama buku teks sebagai pusat pengetahuan dan informasi melalui sebuah pendekatan yang dinamakan Dynamic Immersion Approach. Pendekatan ini mencoba untuk meniru proses anak-anak dalam belajar bahasa. Dari analisis, ditunjukkan bahwa meskipun banyak keuntungan dari pendekatan baru, program ini tidak dapat menghasilkan bahasa alami karena tidak memiliki kemampuan memproduksi bahasa informal.
\end{abstract}

Kata kunci: pembelajaran bahasa, Dynamic Immersion Approach 


\section{INTRODUCTION}

Commonly people are taught to learn language through studying and memorizing rules in grammar book, or drilling through sets of monotonous activities. But now, with the fast pace of information technology, people has more options to learn. Can people rely on old classic learning materials such as book anymore? More than two decades ago, Dowlin (Dowlin, 1991) has predicted that the functions of books commonly found in the conventional library are gradually left behind. With the fast pace of communication technology users now prefer learn language through sets of its interactive activities rather than lurking around the dusty shelf to find books.

The major issues of this paper will cover: firstly, what is the ideal concept of learning language according to experts nowadays? Secondly, what is the most preferred way to learn language? And lastly, to consider a new approach called the dynamic immersion approach as the newest finding in learning language.

\section{RESEARCH METHOD}

This research is using library research meaning the researcher is seeking information in collections of information materials such as books, journals, periodicals and other information. It relies heavily on the works of others such as articles or papers published in journals and proceedings. However, since the nature of this paper is to propose a new theory or notions, the methodology is not need discussing or testing about certain theories.

The research materials are determined from the type of resources namely primary and secondary resources. Primary sources enable the researcher to get as close as possible to what actually happened and it reflects the individual viewpoint of a participant or observer. These materials ranging from diaries, journals, speeches, interviews, letters, memos, manuscripts, records of or information collected by government agencies. The secondary source is measured by the 'distance' between the source with the writer. According to Lester (Lester \& Lester, 2004), this type of source interprets and analyzes primary sources. These sources are one or more steps removed from the event such as textbooks, magazine articles, histories, criticisms, commentaries, encyclopedias, pictures, quotes or graphics of primary sources in them.

This article, however, suggest a further research using a much advanced methodology to expand the view of this paper such as through field research or qualitative sampling research method.

\section{RESULTS AND DISCUSSION}

\section{"Language acquisition does not require extensive use of conscious grammatical rules, and does not require tedious drill." (Krashen, 2011)}

What is the best a way for someone in learning a language. From the quotation above, it can be concluded that language learning should be fun. Unfortunately, in many countries including Indonesia, the teaching of second languages has turned into a complex classroom ceremony, consisting of complicated application of grammar rules, drills, memorization and tests. The result is that many people are discouraged from learning languages. 
Krashen's insights are being confirmed by another research on how the brain learns, as proposed by Manfred Spitzer in his book Learning: The Human Brain and the School for Life. Spitzer says, learning takes place in the brain, not at school. Here, Spitzer mentioned that learning is a natural process and human brain have all the capacity to absorb, adapt, adjust, and use when needed (Spitzer, 2008). He also underline that human brain can find its own way of understanding new language as long as it is given a stimulus such as strong motivation and interesting context.

In line with Krashen and Spitzer, Steven Kaufmann, a language practitioner stressed the importance of the 'naturalness' in learning language in his personal blog 'pick the brain', which has been reviewed by many scholars and language practitioners (Kaufmann, 2009). He combined Krashen's, Spitzer and many other sources into the so called the seven concepts of natural language learning namely:

(1) The Brain can Learn Languages, Trust it. The brain can build an understanding of a language. Just give it some time, and it can develop its rules and prioritize, which one needs to be learned first; (2) The brain needs stimulus. Give it massive amounts of meaningful input. If a learner wants to learn language fast, the he or she need a new, fresh and interesting content. It can be found through stories, conversations, movies and anything that considered important for the learners; (3) The brain will miss things. We can help the brain notice the language. Despite reviewing grammar rules, learners should learn more through massive amount of inputs. These inputs should be practiced into meaningful utterances to increase awareness of the brain about the language patterns, sounds, and context;

(4) Learn to engage your emotions in order to increase learning efficiency. To make learning effective, learners need to like the subject. Uninteresting learning tasks, or negative tension, decrease learning efficiency and effectiveness. Use text with audio visual materials to help learners understand the language through unspoken language or culture such as facial expression and gestures; (5) When you learn naturally, you will feel motivated by your own success. Language learners are usually skeptical of their ability to learn, since they never done it before. Teachers, on the other hand, should encourage learner to become an independent learner, rather than to impose tasks or explanations on the learner;

(6) When we learn, we change. We need to accept this change. When a person learns a new language, he or she adopt some of the behavior patterns of another culture that makes personalities and perceptions change. Compared to children who eagerly imitating the new language they've just heard, many adults resist to change. Most of them find that it is more comfortable to follow the patterns and pronunciation of his or her own language, rather than to commit to fully imitating the new language; (7 The Internet - the new world of natural learning at our finger-tips. If the cost of learning language is an issue, people can use the internet to get lessons from low-cost websites, online tutors, and many free resources. The internet becomes the classroom, the library, the source of content, the language laboratory, and the support community. The Internet enables learner to learn language naturally.

\section{Challenges in learning second language}

From the discussion above, it is clear that learning a new language is like having a new life experience. It is not just a process of combining new words and sentences. The fact is, learning a second language requires an understanding of the language itself and other factors such as culture and other social issues.

Katherine Maitland (1997) in Adding English: helping ESL Learners Succeed mentioned that when a learner need to acquire a new language, learners should prepare and use everything they have including culture, background, and environment. 
Culture will determine speaker perceptions and misunderstandings, whereas their comprehensive ability is based on their first language, which is the basic to understand a concept. Mastering a first language is a must in order to be able to communicate with others. The more someone has been exposed by education. It will determine the success of his or her quest in learning second language. This also includes personal experience especially in dealing with another culture, which will help in overcoming the cultural problems and misunderstandings. The last factor is environment. If learners learn new language, they should expect for surprises. Sometimes it is comfortable and sometimes it is not. Just be prepared and enjoy the ride.

Besides internal factors as mentioned above, there are external factors that learners must consider before, during and after learning a new language. In the same book, Maitland (1997) mentioned that when learning a new language, learners must learn new sounds, which require learners to change their speaking habits. There are new sounds to be learned, which could be strange in learner's ears and organs of speech. Another factor is grammar. Every language has its own grammar and learners should understand the rules and conventions (Maitland, 1997).

Acquiring new vocabulary will also essential for language learners. New word means new vocabulary and new meaning, and learners could understand new vocabulary through reading passage and contextual conversations. During the conversation, learners need to be able to differentiate them in different context and situation. Awareness of certain social context requires fully understanding of cultural elements of certain culture. Therefore, a second language learner should understand the basic of culture in many different situations. After learners understand about all of those factors, they also need to be able to maintain a conversation as long as it can, which require an advanced understanding of using different language to say things appropriately in different social contexts. These language functions should be able to be expressed correctly while considering its cultural context.

From Kaitland's opinion, it can be concluded that in order to be successful, a learner needs to change his or her attitude about learning a language. It is important to note that learning language is a process that requires significant amount of time. This is in line with an article written by Stephen Krashen, which says that by learning another language will make brain to work and process better. And there are many physical and psychological advantages that people can have by being a bilingual rather than as a monolingual person (Krashen, Keep Your Brain Young: Read, Be Bilingual, Drink Coffee, 2010).

\section{Approaches in Learning Second Language}

\section{Grammar Translation Method}

According to Celce - Murcia, the Grammar Translation Method (GTM), or sometime called as Classical Method is the oldest language learning method. It began in the early $20^{\text {th }}$ century and it was used for the purpose of helping students appreciate foreign language. Mostly the focus is through the study of the grammar as the target language (Celce - Murcia, 2000).

The fundamental purpose of learning a foreign language through GTM is to be able to read literature written in the target language. Therefore, it is thought that students need to learn about the grammar rules and vocabulary of the target language. And since the main goal is to make learners able to read literature written in another language, the literary language is superior to spoken language.

Teacher is the authority and teaching - learning process is facilitated through attention to similarities between the target language and the native language. The grammatical rules, agreements and conventions should be memorized. And since literary language is perceived as ultimate goal, culture is not important. It is only part of literature and fine arts. 
Diane Larsen-Freeman, in her book Techniques and Principles in Language Teaching (Larsen - Freeman \& Anderson, 1986) describes some common/typical techniques closely associated with the Grammar Translation Method. The summary is as follows: (1) Translation of a Literary Passage (Translating target language to native language); (2) Reading Comprehension Questions (Finding information in a passage, making inferences and relating to personal experience); (3) Antonyms/ Synonyms (Finding antonyms and synonyms for words or sets of words); (4) Cognates(Learning spelling/sound patterns that correspond between L1 and the target language); (5) Deductive Application of Rule(Understanding grammar rules and their exceptions, then applying them to new examples); (6) Fill-in-the-blanks (Filling in gaps in sentences with new words or items of a particular grammar type); (7) Memorization (Memorizing vocabulary lists, grammatical rules and grammatical paradigms); (8) Use Words in Sentences (Students create sentences to illustrate they know the meaning and use of new words); (9) Composition (Students write about a topic using the target language).

\section{E- learning}

Language can be learned through e- learning. In e-learning where the word $e$ stands for electronic, there are two key technological pieces involved in it: the digital library and the internet. The e-learning, which is heavily involved the information and communication technology (ICT), has radically changed the potential for support of schooling. (Schneiderheinze, 2005)

There are tools needed for establishing a solid and comprehensive e-learning system. The most crucial tool that helps learners to visually review, capture, or develops subject matter is the concept mapping. The idea of concept mapping is to help both learners and instructors engage in an active learning process when they construct spatial-semantic displays of the knowledge, concepts, and skills that the learner possesses and acquires (Kremer \& Gains, 1994). Concept mapping is a knowledge visualization tool, which can provide both a "course map" view of instructional topics and a methodology to support personal knowledge acquisition. This process of building a personal knowledge representation aligns closely with the formulation stage of the information search process.

First thing before Concept mapping for education was introduced as a technique to support meaningful learning (Novak \& Gowin, 1984). Kremer and Gaines in Groupware Concept Mapping Techniques found that students involved in concept mapping exercises achieved both good results and exhibited high levels of task-focused behavior. (Kremer \& Gains, 1994). Regev additionally considers concept maps a primary metaphor for a collaborative virtual environment. He emphasizes on the value of concept maps for collaboration and the constructivist notion that knowledge is gained in a social context suggest the potential of concept mapping as an appropriate tool for an integrated learning environment (Regev, Gilbert, \& Wegmann, 2001)

The integration of e-learning in language learning seems quite promising in improving learner's learning result. However, it should be noted that any technology is pedagogically neutral and can therefore be applied to different aspects of pedagogy. The educational approach or philosophy is more important than the selection of the technology itself; pedagogical methods utilizing even the simplest technologies can be extremely effective. Unfortunately, this is not the case in most existing elearning systems, as technology considerations seem to take on a more important role than pedagogy. And although the introduction of information and communication technologies into education has improved the learning process, aided in building our knowledge base, and increased our multiple intelligences, the technologies should be seen only as vehicles for delivering learning content. (Dalgarno, 2001) 


\section{Dynamic Immersion Approach}

Compared to a traditional language-learning class there is a little or even no opportunity for learners to understand a contextual language. When learner sees some shops, street signs, English announcement, they cannot relate to what they have just learned. The language that they studied cannot make them speak.

In the researcher's opinion, the Grammar - Translation Method (GTM) that usually practiced in classic classroom simply is not fit for the needs of the learners nowadays since it only focuses on improving grammar, reading and writing skills. It does not touch the essential element of communication: producing understanding utterances.

In the case of the grammar-translation method (GTM), for example, learners learn to depend upon translations and grammar explanations in our native language even though the grammar translation method itself usually accounts for our failure to speak the language. We venture out into the world nonetheless, fortified with translation-based dictionaries and phrase-books hoping we'll learn to speak. But the method gets in the way.

Therefore, the suitable method, is a method for learning to speak a language that lead learners all the way through the process, beginning to end, and delivers real communicative value regardless of the context. It should cover: self-study, conversations around town, or in-country. Duane Sider (2010) calls this feature as "exponential-learning.

” It is a method that multiplies its value in each new setting. It is a completely natural language-learning method for self-study (x) that builds your conversation skills with live native speakers at the same time (x2) and gives learners exactly the strategies and tactics you need to continue learning when you're surrounded by native speaker incountry (x3).” (Sider, 2010)

The approach suitable for this goal can be found in many language learning computer software such as the one published by Rosetta Stone ${ }^{\circledR}$. The approach is popularly called as "Dynamic Immersion Approach" that tries to imitate the process of learning language by children. Similar to Kauffman's opinion, this software depends highly on audio visual to illustrate context. There are no tedious grammatical drills, boring reading text and monotonous exercises. (Kaufmann, 2009)

Cyrus Farivar, a language practitioner and a writer, wrote an article in Macworld about the software. He underlines the capability of the software where it enables learners to experience language through many sources and context. The program starts with a text and an image to choose. It begins with simple words such as "boy," "girl," "cat” and "dog." In the exercise, the program speaks the new language's word for "a boy," writes it across the top of the screen, and displays one of four images to choose from. (Farivar, 2006)

Farivar (2006) also wrote that the users are encouraged to try and the program will give awards for every correct answer. This program also lets user to choose the format such as: spoken text with four photos to choose from, a photo and four spoken words to choose from, a photo and four written texts to choose from, or a written text and four spoken words to choose from. These varied methods allow you to practice verbal, listening, and reading comprehension.

What is interesting about this program is that it continues in each pattern, expanding to personal subjects such pronouns, tenses, numbers and many other language elements. The program is designed to recycle previous lessons by incorporating words and phrases from the previously learned content to the next. By using the past lessons, it is easier to learn and remember specific words or phrases. 
The writer tends to agree that the dynamic immersion approach is the closest approach possible in language learning since it fulfills the requirements of an ideal language learning materials of: contextual, interactive, easy to use, free of tedious exercise and flexible. The software itself can be installed in computers to make learning interesting both for in class and private learning. The progress can be traced from the exercises that the learners has done. Teachers can measure learner's improvement by conducting simple interview.

Despite all of those advantages, dynamic immersion software cannot be used for informal needs. This software has limited ability to learn in a casual way. Like most language textbooks, the program focuses more on formal speech than on native speakers' common ways of using the language. The program sometimes uses words that native speakers would understand, but would not frequently use.

\section{CONCLUSION}

In general, learning a second language is not much different from years to years. The most obvious difference, however, is on the demand of learners. Nowadays, learners need second language for communicative purpose in many settings. Ironically, this need is not realized by education institutions. Instead of changing its approach, many schools still maintain its classical approach by teaching its students through learning grammar rules, doing tedious drills, and memorization. The result can be seen in most school students. Most of them cannot speak or understand utterances. Or even worse, some of them thought that learning second language is a terrifying experience.

The new approach in learning a language is by learning it naturally. Like children who learned their first language, the approach try to imitate how children mimicking other person when they learn a language. One software company called Rosetta Stone ${ }^{\circledR}$ offers a software that uses a dynamic immersion approach. It is a new approach that combines the power of audio visual with a clear context. This software, according to experts and users can make learners learn language without feeling distressed since there is no tedious grammar and boring reading exercises.

On the other hand, although learning language can be assisted by technology, human factors still play major role in the process of learning language. Experts such as Krashen, Maitland and Kauffman agree that learning second language should be fun. Therefore, the writer suggests that language learners and practitioners should have positive attitude toward language teaching learning, and focus on the process that lead to understanding rather than instant result.

\section{REFERENCES}

Celce - Murcia, M. (2000). Teaching English as a Second or Foreign Language, 3rd Edition. Michigan: The University of Michigan Press.

Dalgarno, B. (2001). Interpretations of Constructivism and Consequences for Computer Assisted Learning. British Journal of Educational Technology, 183-194.

Dowlin, K. E. (1991). Information technology and library, 311 - 316.

Farivar, C. (2006, January 19). Fairfield Language Technologies Rosetta Stone 3.0. MacWorld. 
Kaufmann, S. (2009). 7 Concepts of Natural Language Learning. Retrieved May 20, 2011, from Pick The Brain Grow Yourself: http://www.pickthebrain.com/blog/language-learning/

Krashen, S. (2010, October). Keep Your Brain Young: Read, Be Bilingual, Drink Coffee. Language Magazine.

Krashen, S. (2011). Stephen Krashen's Theory of Second Language Acquisition. Retrieved July 20, 2011, from Schutz \& Kanomata ESL: http://www.sk.com.br/sk-krash.html

Kremer, R., \& Gains, B. R. (1994). Groupware Concept Mapping Techniques. SIGDOC, 156-165.

Larsen - Freeman, D., \& Anderson, M. (1986). Techniques and Principles in Language Teaching (3rd ed.). Oxford University press.

Lester, J., \& Lester. (2004). Writing Research Papers. New York: Pearson Education.

Maitland, K. (1997). Adding English: Helping ESL learners succeed. Good Apple.

Novak, J. D., \& Gowin, D. B. (1984). Learning How to Learn. Cambridge: Cambridge University Press.

Regev, G., Gilbert, X., \& Wegmann, A. (2001). Collaborative Concept Mapping on the World Wide Web. IAMOT Conference.

Schneiderheinze, D. D. (2005). MODEL FOR E-LEARNING CURRICULUM: DIFFERENCES FROM TRADITIONAL CLASSROOM CURRICULUM. Carbondale: Southern Illinois University Carbondale.

Sider, D. (2010, December 3). Rosetta Stone Squared: How ‘Exponential Learning’ Gets You Talking. Retrieved July 20, 2011, from R Voice: http://blog.rosettastone.com/2010/12/03/rosetta-stonesquared-how-exponential-learning-gets-you-talking/

Spitzer, M. (2008). Learning Human Brain and the School for Life. Elsevier Science. 